\title{
Exploring Accounting Fraud In The Subsidiary Environment
}

\author{
Carmelita Troy, Andrews University, USA \\ Madeline Ann Domino, University of Central Florida, USA \\ Steven P. Landry, Monterey Institute of International Studies, USA
}

\begin{abstract}
This research explores accounting fraud in the subsidiary environment. Utilizing institutional theory, we propose that the subsidiary environment provides an opportune setting and vehicle for individuals to commit accounting fraud. While a growing body of literature exists on accounting fraud, minimal work has focused on the role of the subsidiary in accounting fraud, as reported by the Securities and Exchange Commission (SEC). We sample companies for which the SEC has documented accounting fraud in their enforcement releases. We then analyze the related SEC documents to determine to what extent, if any, a subsidiary is involved in the accounting fraud. Our preliminary results provide evidence related to the industries, circumstances and types of accounting fraud that take place in a subsidiary environment. These findings provide auditors, regulators, and designers of management control systems with additional insights as to the factors surrounding fraud when companies operate in a subsidiary environment.
\end{abstract}

Keywords: accounting fraud, subsidiaries, auditing

\section{INTRODUCTION}

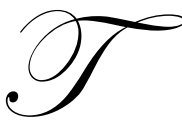

he title quotes an old Chinese saying. In ancient China, given the size and magnitude of the country and the anomalies extant within the communication capabilities of the time, the outlying provinces often tended to eschew following Imperial "policy" in order to pursue paths of personal aggrandizement. After all, when so far from the epicenter of power, and importantly scrutiny, why not 'take a little (or a lot) off the top'. Who's to know? As one might suspect, and as history points out, such lack of goal congruence led to all sorts of problems for the Chinese nation. Intriguing how history repeats itself. Only now, the new empires are Multinational Corporations (MNCs). Instead of calling the outlying areas provinces, we call them subsidiaries. Instead of committing treason, we call it committing fraud.

Interest in corporate accounting fraud has reached an all time high since the demise of Enron, WorldCom, Tyco and others. Passas (2001) reports that because of the ease with which accounting fraud can be executed, the number of accounting frauds are high and quite possibly rising. These circumstances have served to highlight the significance of this problem by the popular press, academics, auditors, and regulators, such as the Securities and Exchange Commission (SEC). We suggest that the subsidiary environment, very much analogous to the ancient provincial environment of China, presents an opportune setting in which accounting fraud may take place, whether concealed or facilitated. To date, little academic literature has focused on the role of the subsidiary environment as it relates to accounting fraud.

Prior research on accounting fraud offers evidence of the motivations surrounding these events. These include attempts by management to secure external financing at a lower rate to avoid violating debt covenants (Dechow et. al., 1996); to stabilize or "manage" the corporate earnings stream to positively impact the value of a firm (Beidleman, 1973); and to meet analysts' earnings targets. The Securities \& Exchange Commission (SEC) has documented that fraudulently overstated earnings and other accounting frauds often associate with the inability of firms to meet earnings targets through legitimate means. 
We define accounting fraud as violation of the SEC Act of 1934, as documented in the SEC Accounting and Auditing Enforcement Releases (AAERs). These violations include the failure to file with the SEC annual financial reports in compliance with Generally Accepted Accounting Principles (GAAP), the falsification of records required by the SEC, and false financial reporting with deliberate disregard for the truth. Accounting fraud involves violation of securities law, specific laws such as the Foreign Corrupt Practices Act (FCPA), or GAAP, and/or situations that involve poor or circumvented internal controls.

To this end, we analyze AAERs issued by the SEC relating to enforcement for accounting violations to determine the extent to which evidence exists associating subsidiaries with accounting fraud. When such associations exist, we describe the relationship(s) the SEC documented between a subsidiary or subsidiary-related activities and the accounting fraud.

This paper is organized as follows. First, we present a literature review which focuses on accounting fraud and subsidiaries. Next, we present the theoretical foundation for the research, the main research question and methodology. Then, we provide some examples of the fraudulent activities relating to subsidiaries that the SEC documented in its enforcement releases. Finally, we conclude with a discussion of our findings to include some prescriptive thoughts.

The results of the research contribute to the body of accounting research in a number of ways. First, we provide a descriptive view of the occurrence of fraud as it relates to subsidiaries as documented by the Securities \& Exchange Commission. Second, we provide information useful to auditors in the course of the attestation function. Third, we provide some thoughts integrating internal controls from a management control system perspective to ex ante addressing fraud, 'nipping it in the bud', so to speak. Finally, our findings add to the body of knowledge within the accounting literature on accounting fraud.

\section{REVIEW OF THE LITERATURE}

\section{Accounting Fraud}

A growing body of empirical literature on accounting fraud continues to develop as investigators and academics attempt to explore why and how such occurrences take place. In a 1996 study, Dechow, et. al., explored accounting fraud by reviewing the AAERs issued by the SEC. Their findings showed that the management of firms involved in accounting fraud were often enticed into using questionable accounting practices in order to obtain external financing at a lower cost than otherwise possible.

Researchers have also documented findings on fraudulent accounting practices. For example, Gerety and Lehn (1997) found increased instances of accounting fraud in companies that had large expenditures for assets that proved difficult for investors to value, such as research and development. Beneish (1997) observed that large discretionary accruals were related to accounting fraud, while Lee, et. al., (1999) showed that fraudulently reported accounting income based on accrual methods was significantly higher than operating cash flows in the period before discovery of the fraud. In addition, prior research has clearly established the motivation for or enabling of accounting fraud. Such management motivation or 'enabling' includes executive incentive programs (Beneish, 1999; Summers \& Sweeney, 1998), the need to manage debt (Watts and Zimmerman, 1990 and Christie 1990), ineffective governance structures and independence, and quality of the audit (Dechow et al, 1996; McMullen, 1996).

\section{Accounting Fraud And Earnings Management In Subsidiaries}

As previously mentioned, minimal empirical work to date has linked accounting fraud or earnings management with subsidiaries, or explored the motivation of management to engage in fraud in subsidiary-related circumstances. In a study which investigated global accounting fraud, Badawi (2005) reported that in most cases of fraud by multi-national firms, a foreign subsidiary of the firm committed the impropriety. Badawi (2005) suggested that mid-level managers of subsidiaries fraudulently misreported financial results in order to meet company-set earnings targets or to hide poor performance. Krull (2004) reported that multi-national firms manage earnings 
reported in consolidated U.S. financial statements by "permanently reinvesting" foreign earnings in foreign subsidiaries as a means to avoid reporting the earnings and paying taxes in the U.S.

Subsidiaries are sometimes purchased as part of a merger or acquisition. Schilit (2002) provided evidence of earnings management relating to acquisitions activity involving subsidiaries. Easterwood (1997/1998) has shown that target firms systematically manage earnings upward in the periods prior to being acquired.

\section{Theoretical Foundations}

Academics have long used institutional theory as a way to explain formal legitimacy as the primary objective of organizational change. In this context, organizations (and management) adapt their internal characteristics in order to conform to the expectations of the key stakeholders in their environment (Ashworth et al, 2005). We assumed that perceived motives and consequences in the subsidiary environment provided a formal legitimacy to those individuals who committed accounting fraud. Further, Pfeffer (1982) and Pferrer \& Salancik (1978) noted the existence of many incompatible mandates and expectations which increased the pressures on managers of firms.

In a study exploring institutional theory, DiMaggio and Powell (1983) identified a number of ways in which organizations face pressures to conform to forms and processes deemed legitimate. One such pressure has been labeled as coercive force, an example of which is the expectation to meet a certain target level for revenues and/or earnings growth. According to DiMaggio and Powell, coercive forces represent external pressures exerted by government, regulatory or any other agencies to adopt the structures or systems which they condone. Often these pressures are associated with earnings expectations.

Scott (1987, p. 502) comments that "an institutional perspective gives special emphasis to authority relations: the ability of organizations, especially public organizations, to rely on legitimate coercion." If outside pressures conflict with legitimate procedures, management may rely upon rationalized expediency in making decisions. Thus, we propose that as individuals within the firm strive to meet legal and contractual obligations, coercive forces and pressures may induce them to engage in fraudulent accounting. SEC investigations provide a window to view accounting fraud as it relates to the subsidiary environment.

\section{Major Research Question}

We attempt to investigate the following research question:

What industries, circumstances and types of accounting fraud are documented by the SEC for firms that operate in a subsidiary environment?

\section{METHODOLOGY}

This research explores the industries, circumstances and types of accounting fraud documented by the SEC for firms that operate in a subsidiary environment. We define accounting fraud as violations of sections 10(b), 13(a) and 13(b) of the Securities Exchange Act of 1934. We utilize the Securities and Exchange Commission Accounting and Auditing Enforcement Releases (AAERs) as our data source. This SEC database provides clear descriptions of the circumstance surrounding enforcement activity and accounting fraud. For example, each enforcement action release gives detailed information about the firm, the individuals involved in the fraud, the violation that occurred, when it occurred, and sections of the Securities Exchange Act of 1934 that were violated. Brief descriptions of these sections of the Securities and Exchange Act are:

1. Section 10(b) prohibits false financial reporting or financial statements made with deliberate disregard for the truth; 
2. Section 13(a) requires firms to file annual reports with the SEC and that filings must be in conformity with Regulation X; and Regulation X requires that financial information be presented in conformity with Generally Accepted Accounting Principles (GAAP); and

3. Section 13(b) forbids the falsification of any financial records.

We rely on the assumption that the SEC correctly identified those firms that committed an accounting fraud and the relevant circumstances that surrounded the accounting impropriety. Given prior studies that utilized the SEC AAER for accounting fraud research, and the fact that the SEC has a strong protocol for identifying firms where fraud has taken place (DeChow et. al., 1996; McMullen, 1996; Beasley et. al., 2000; Kaminski et. al., 2004; Persons, 2005), we believe in the validity of this assumption.

\section{Preliminary Sample Selection}

We chose the period January 1998 through October 2005 for our investigation of firms involved in accounting fraud as documented by the SEC. Over the study period, 156 firms were sanctioned for accounting fraud by the SEC as documented in the AAERs.

To conduct this examination, two of the authors independently read the SEC AAERs and other related documents for any references to the accounting fraud in the subsidiary environment. The process we use for data collection involves conducting a "find" search in the AAER and related SEC documents, using the following term subsid*. By using the asterisk (*), we found in the documents words such as "subsidiary" or "subsidiaries". We believe that by using this search approach, and by examining the text, we found the activities, events, and discussion regarding accounting fraud in the subsidiary environment. We compared our results and agreed upon the companies to use in the study and to the broad classifications of subsidiary accounting fraud that we discuss herein.

\section{Descriptive Statistics \& Data Analysis}

Our search resulted in a subsidiary fraud sample of thirty nine (39) firms, or twenty five percent (25\%) of the total of all firms, in which the AAER documents described a relationship between a subsidiary and the perpetrated accounting fraud. For this sample, we grouped the firms into broad categories which best described the type of fraud documented in the AAERs. We created these classifications in an attempt to delineate both the type and the source of the fraud, so that we might analyze them for patterns and relationships. We defined these classifications based on the language found in the AAERs. Table 1 outlines the types of fraud identified in the subsidiary environment in the sample firms.

Table 1

Type of accounting fraud discussed in the Accounting \& Auditing Release; 39 firms involving subsidiary fraud

\begin{tabular}{lcc}
\hline \multicolumn{1}{c}{ Type of Fraud } & Number of Firms & Percentage \\
\cline { 2 - 3 } Overstatement of Revenues & 25 & $64 \%$ \\
Understatement of Expenses & 6 & $15 \%$ \\
Disclosure & 2 & $5 \%$ \\
Understatement of Reserves & 1 & $3 \%$ \\
Illegal /Unrecorded Payments & 2 & $5 \%$ \\
Other Income Increasing Effects & $\underline{3}$ & $8 \%$ \\
$\quad$ Total. & $\underline{\underline{39}}$ & $\underline{100 \%}$ \\
\hline
\end{tabular}

Overstatement of revenues in a subsidiary constituted the type of accounting fraud most frequently perpetrated, i.e. 25 of the firms (64\%). Understatement of expenses in a subsidiary in 6 firms (15\%) followed as second. Accounting fraud took place in the form of "other income increasing effects" involving a subsidiary in three firms (8\%). The remaining types of subsidiary fraud involve failure to disclose debt, understatement of reserves, or illegal payments related to the Foreign Corrupt Practices Act. 
Table 2 presents a breakdown of the sample firms included in the AAER by the type of subsidiary, i.e., foreign or domestic, and whether there existed an indication that a merger, acquisition, or reorganization played a role in the perpetration of the accounting fraud. The fraud occurred in foreign subsidiaries about $1 / 3$ of the time and a full $2 / 3$ rds of the time the fraud related to domestic subsidiaries.

Table 2

Type of Subsidiary and Relationship to Mergers, as discussed in AAER; 39 firm sample

\begin{tabular}{lcc}
\hline & 39 firm sample & $\underline{\text { Percentage }}$ \\
Foreign Subsidiary & 10 & $26 \%$ \\
Foreign Subsidiary, merger related & 3 & $8 \%$ \\
& & $54 \%$ \\
Domestic Subsidiary & 21 & $\underline{13 \%}$ \\
Domestic Subsidiary, merger related & $\underline{5}$ & $\underline{100 \%}$ \\
\hline
\end{tabular}

We classified the sample firms using the two-digit Standard Industrial Classification (SIC) Code. Table 3 denotes the industry classification of the 39 firms in the sample. Business services (SIC code 73) with eight observations makes up the largest industry grouping, followed by chemical and allied products (SIC code 28), communications (SIC code 48), and electronic \& other electrical equipment (SIC code 36) each with 4 observations each. The business services classification includes a high percentage of firms involving the computer and telecommunications industry.

Table 3

Two-digit SIC Industry classification

of 39 firms with subsidiary subject to enforcement actions by the SEC between January 1998 and October 2005

\begin{tabular}{clcc}
\hline SIC & Name & $\underline{\text { obs }}$ & $\underline{\%}$ \\
13 & oil \& gas extraction & 1 & $5.1 \%$ \\
20 & food \& kindred products & 1 & $2.6 \%$ \\
27 & printing \& publishing & 4 & $10.3 \%$ \\
28 & chemical \& allied products & 1 & $2.6 \%$ \\
30 & rubber \& misc plastics & 2 & $5.1 \%$ \\
34 & fabricated metal, ex machinery & 4 & $10.3 \%$ \\
35 & industrial machinery \& equip & 2 & $5.1 \%$ \\
36 & electronic \& other electric equip & 1 & $2.6 \%$ \\
38 & instruments \& related products & 1 & $2.6 \%$ \\
42 & trucking \& warehousing & 4 & $10.3 \%$ \\
48 & communications & 1 & $2.6 \%$ \\
49 & electric gas \& sanitary svcs & 3 & $7.7 \%$ \\
50 & wholesale trade \& durable goods & 1 & $2.6 \%$ \\
51 & wholesale trade \& nondurable goods & 2 & $5.1 \%$ \\
54 & food stores & 7 & $17.9 \%$ \\
73 & business svcs & 1 & $2.6 \%$ \\
80 & health svcs & $\underline{1}$ & $\underline{2.6 \%}$ \\
87 & engineering \& management & $\underline{\underline{390 \%}}$ \\
Total & & & \\
& &
\end{tabular}




\section{DISCUSSION}

As previously mentioned, institutional theory suggests that firms conform to the expectations of, and coercive pressures from, key stakeholders. The need to meet earnings and revenue targets set by the company itself or by those financial analysts following the company represents one such coercive pressure. In $12(31 \%)$ of the 39 firms in our sample, the enforcement actions contain specific language stating that the subsidiary fraudulently manipulated its accounting records in order to meet earnings targets, earnings projections, revenue estimates, or analysts' expectations. This language provides a clear linkage concerning the pressure to meet these goals.

Table 4 shows the number of reported firms by year. Intriguingly, noting 2001 as the "Enron Year", most reported fraud, covering our 1998-2005 timeframe, occurred "pre-Enron". Undoubtedly, the "recency effect" played a role, along with intensified regulatory scrutiny, in firms taking steps to mitigate fraud post-Enron. If we accept Institutional Theory's positing that managers react to coercive pressures, then government attention particularly in the form of the Sarbanes-Oxley Act (SOX) would seem to have had its intended effect.

Table 4

Year and Number of Firms Identified with Subsidiaries Having Committed Fraud 39 firm sample

\begin{tabular}{|c|c|c|}
\hline Year of the Fraud & Number of Firms & Percent of Firms \\
\hline 1998 & 7 & $17.9 \%$ \\
\hline 1999 & 10 & $25.6 \%$ \\
\hline 2000 & 12 & $30.8 \%$ \\
\hline 2001 & 7 & $17.9 \%$ \\
\hline 2002 & 2 & $5.1 \%$ \\
\hline 2003 & 0 & $0.0 \%$ \\
\hline 2004 & $\underline{1}$ & $2.6 \%$ \\
\hline Total & $\underline{\underline{39}}$ & $\underline{100.0 \%}$ \\
\hline
\end{tabular}

According to SEC documentation, the presence of ineffective controls or the circumvention of controls by management constituted prominent vehicles for initiating and committing fraud leading to overstatement of earnings. Poor controls relating to the authorization of purchases, or recording of accounting entries, were often sited as the means by which internal controls were circumvented, deficient or inadequate. Often, both the parent and the subsidiary "lacked any meaningful internal controls," and the parent "failed to take adequate corrective action in the face of several red flags suggesting a failure of internal controls." ${ }^{2}$ In other instances, the enforcement documents stated that the company violated the "internal controls provisions of the federal securities laws"3 or that acquisition activity placed a strain on internal controls. ${ }^{4}$

The failure of internal controls often led to the primary effect of overstating revenues, and therefore the earnings, in the subsidiary, along with the corresponding overstatement of assets. The SEC enforcement actions often report the amount of the overstatements of earnings in terms of percentage of revenues, pre-tax profit, or net income. These percentages were often substantial and frequently the fraud occurred over an extended period of time. For example, in one company, the fraud related to the subsidiary overstating net income, which in turn resulted in the overstatement of consolidated corporate earnings by at least $117 \%$ and up to $250 \%$ in each of quarter

\footnotetext{
${ }^{1}$ See AAER \#2049, July 6, 2004.

${ }^{2}$ See AAER \#1564, June 5, 2002.

${ }^{3}$ See AAER \#2247, May 19, 2005.

${ }^{4}$ See AAER \#1692, December 16, 2002.
} 
six quarters investigated. Another company overstated net income by $\$ 11.4$ million, which represented $270 \%$ of the net income the company actually earned, with the fraud originating in a subsidiary with poor internal controls.

The method of the overstatement of revenues varied. The SEC reports that many of the subsidiaries spread the fraudulent overstatement of revenues across a number of transactions or journal entries; others, in just one entry. In one subsidiary, as the result of one fraudulent transaction, the company's net income was overstated by $22 \%$ and in another company the subsidiary reported an intra-company transfer of $\$ 2.4$ million of assets as if it were a bonafide sale to a third party, and thereby overstated company net income by $11.5 \%$.

Overstatement of profits can also be achieved by understating expenses. We found that the understatements of expenses occurred either because the subsidiary failed to record some expenses or improperly capitalized expenses. In one case, a subsidiary partially recorded an expense relating to inventory that had declined in value, but had neglected to record $\$ 1.5$ million of the total $\$ 6.2$ million decline. In another case the subsidiary capitalized \$19.4 million of expenditures that should have been expensed. The overall effect of capitalizing the expenses resulted in the magical transformation of massive losses into multimillion dollar profits, thereby meeting earnings targets.

The SEC has cited foreign subsidiaries for accounting fraud. These foreign subsidiaries often have paid bribes to local officials in violation of the Foreign Corrupt Practices Act. The amounts of the illicit payments that result in SEC enforcement action can vary from small to large. According to SEC enforcement release documents, the foreign subsidiary of one multi-billion dollar company made 13 payments (bribes) totaling less than $\$ 76,000$. In another case, on the other hand, the bribes made by subsidiaries in three foreign countries totaled $\$ 1,100,000$. Yet, it is not the payment of the bribe that results in the enforcement action, but rather improperly accounting for the bribe. In other words "it's not the crime, but the cover-up."

Sometimes the fraud is pervasive. One measure of the pervasiveness of the fraud is the number of individuals named in the enforcement actions against a company. While not uncommon for the SEC to take action against the company only with no individuals named in the enforcement releases, at other times, the SEC will name several or many individuals as participating in the fraud. The situation involving the father and three sons in the Rigas family, who perpetrated the fraud at Adelphia Communications, represent a well-known case of pervasive illegal activities and improper disclosures in subsidiaries. Noting another company in our sample, the SEC named seven individuals, from both the subsidiary and the parent, in the enforcement actions against the company. The SEC documents relating to the fraud of another company named at least 15 individuals in the company and from other organizations doing business with the company. Qwest Communications constituted the most extreme case where the SEC named at least 24 individuals as taking part in the fraudulent activities that took place both in the subsidiary and the parent.

Noting the SEC's documentation linking the presence of ineffective controls or the circumvention of controls by management as prominent vehicles for initiating and committing fraud, a brief prescriptive discussion of management control systems is in order. Simons (2000) suggested that a broad management control system should encompass more than simply software and hardware. He laid out a four dimensional "Levers of Control" model including Belief Systems, Boundary Systems, and Interactive Control Systems in addition to the usual Diagnostic Control Systems. Many organizations fail to seriously consider the potential impact of Belief and Boundary Systems, in particular, in giving teeth to their Internal Control Systems. Simons described Belief Systems (or core values) in terms of Strategy as Perspective which he defined as "obtaining commitment to the grand purpose"; and Boundary Systems (or risks to be avoided) in terms of Strategy as Position which he defined as "staking out the territory" (Simons 2007, p. 305).

Perhaps the best way to illustrate how Belief Systems and Boundary Systems can play a significant role in strengthening and enforcing internal controls is to relate an account of a real life situation from a former Chief Executive Officer (CEO) relayed to one of the coauthors at an academic faculty lunch meeting (Lundeen 2003). Mr. Robert Lundeen, the CEO of Dow Chemical Corporation at the time of the incident, was negotiating a major chemical deal with Indonesia. Several high level Dow Chemical officers accompanied Mr. Lundeen in what 
appeared to be the near-final negotiation phase of the deal. When the deal appeared final, the Indonesian delegation, which included in part some government officials, requested Dow Chemical render to the Indonesian delegation an advance payment not found in the contract language. Mr. Lundeen recounted how he immediately negated the deal, got up from the table and left the room along with his team.

Turning to the academics assembled, Mr. Lundeen asked what the group thought of his actions. Some responded that the deal under consideration probably consisted of billions of dollars and would have generated analogous, large future profits. Why would the amount asked by the Indonesian delegation matter even if it was maybe $\$ 100,000$ or even $\$ 200,000$ ? Is not this accepted practice in many Asian countries?

Mr. Lundeen shared his position with the following thoughts. If he as CEO had a high-level subordinate make a poor operational or financial decision that cost Dow Chemical millions, tens of millions or even hundreds of millions of dollars, while not a pleasant prospect, he would not necessarily proceed with any punitive action against that subordinate. Certainly, one could find fault in the decision making of the subordinate, but such risks simply make up the business world. If, however, he found out that anyone had taken anything even bordering on the possibility of a bribe, even for a trivial amount, he would immediately terminate such a person. He could send no clearer message. Dow Chemical not only had a set of belief and boundary systems in place, he would enforce those systems as part of an integral internal controls system.

The failure of the second instance, the taking of a bribe, would endanger the firm not only in the immediate timeframe, but also had the potential for increasingly greater payments siphoned off due to extortion. Ultimately, the firm would run the ultimate franchise risk of ruining its reputation and go the way of Arthur Andersen into oblivion. The moral of the story relayed the importance on not simply having the usual internal control systems in place, but rather ensuring those systems are complemented with emphatically communicated, supported, and enforced belief and boundary systems allowing no room for fuzzy interpretation. Perhaps such leadership and system implementation would have gone a long way in discouraging the fraud and misrepresentation of the firms noted by the SEC documentation in the above discussion.

\section{CONCLUSIONS}

The findings presented in this paper represent our initial investigation of the relationship between accounting fraud and subsidiaries as documented by the SEC. Our research found that SEC investigations frequently document an association of accounting fraud and subsidiaries, both at the domestic and foreign levels. We found that this association can fall into a broad spectrum of categories. However, the primary vehicle for perpetrating accounting fraud at the subsidiary level fell into the category of improperly accounting for subsidiary transactions that resulted in overstatement of income by either overstating revenues or understating expenses. Inadequate, circumvented, or incomplete internal controls played a key role in the facilitation of the fraudulent activities.

These findings represent an initial analysis of a much needed, more complete study on this topic. Our initial findings suggest that fraud often occurs in the subsidiary environment, with the SEC documenting subsidiary accounting fraud for $25 \%$ of all companies examined in our research. This indicates that auditors, regulators and management should emphasize an examination of subsidiaries in their attempts to determine the extent to which accounting fraud or irregularities may occur. Our findings support prior research that show adequate internal controls are essential to prevent the perpetration of accounting fraud. Therefore, internal and external auditors should not only test internal controls are working as intended, but should also investigate the ways that internal controls can be circumvented at both the parent and subsidiaries.

\section{REFERENCES}

1. Ashworth, R., G. Boyne, R. Delbridge. 2005. Institutional pressure on public organisations: An empirical test of isomorphism. Management Research News. 28(9): 61-62. 
2. Badawi, I. M. 2005. Global corporate accounting frauds and action for reform. Review of Business. 26(2): 8-14.

3. Beasley, M. S., J. V. Carcello, D. R. Hermanson, and P. D. Lapides. 2000. Fraudulent financial reporting: Consideration of industry traits and corporate governance mechanisms. Accounting Horizons 14 (4):441454.

4. Beneish, M. D. 1997. Detecting GAAP violations: Implications for assessing earnings management among firms with extreme financial performance. Journal of Accounting and Public Policy 16:271-309.

5. Beneish, M. D. 1999. The detection of earnings manipulation. Financial Analysts Journal 55(5):24-36.

6. Beidleman, C. 1973. Income smoothing: The role of management. The Accounting Review. XLVII (4): 663- 667.

7. Christie, A.A. (1990) Aggregation of Test Statistics: An Evaluation of the Evidence on Contracting and Size Hypotheses. Journal of Accounting and Economics. 12: 15-36.

8. Daboub, A. J., Rasheed, A. M. A., Priem, R. L., \& Gray, D. A. 1995. Top management team characteristics and corporate illegal activity. The Academy of Management Review. 20: 138-170.

9. Dechow, P. M., R. G. Sloan, and A. P. Sweeney. 1996. Causes and consequences of earnings manipulation: An analysis of firms subject to enforcement actions by the SEC. Contemporary Accounting Research. 13 (1):1-36.

10. DiMaggio, P. J., and Powell, W. (1983) The iron cage revisited: Institutional isomorphism and collective rationality in organizational fields. American Sociological Review, 48: 147-160.

11. Easterwood, C. M. 1997/1998. Takeovers and incentives for earnings management: An empirical analysis. Journal of Applied Business Research. 14(1): 29-47.

12. Gerety, M. \& Lehn, K. 1997. The causes and consequences of accounting fraud. Managerial and Decision Economics. 18: 587-599.

13. Kaminski, K. A., T. S. Wetzel, L. Guan. 2004. Can financial ratios detect fraudulent financial reporting? Managerial Auditing Journal. 19(1):15-28.

14. Krull, L. K. 2004. Permanently Reinvested Foreign Earnings, Taxes and Earnings Management. The Accounting Review. 79(3): 745-767.

15. Lee, T. A., Ingram, R. W., \& Howard, T. P. 1999. The difference between earnings and operating cash flow as an indicator of financial reporting fraud. Contemporary Accounting Research. 16: 749-786.

16. Lundeen, R. 2003. Discussion comments at meeting with faculty of the Monterey Institute of International Studies. Monterey, CA.

17. McMullen, D. 1996. Audit committee performance: An investigation of the consequences associated with audit committees. Auditing. 15: 87-103.

18. Passas, N. 2001. False Accounts: Why do company statements often offer a true and fair view of virtual reality. European Journal on Criminal Policy and Research. 9(2): 117-135.

19. Persons, O. S. 2005. The relation between the new corporate governance rules and the likelihood of financial statement fraud. Review of Accounting \& Finance. 4(2):125-149.

20. Schilit, H. M. 2002. Financial Shenanigans, $2^{\text {nd }}$ edition. New York: McGraw-Hill.

21. Scott, W. R. 1987. The Adolescence of Institutional Theory. Administrative Science Quarterly. 32(4): 493-511.

22. Simons. R. 2000. Performance Measurement \& Control Systems for Implementing Strategy. Upper Saddle River, New Jersey: Prentice-Hall.

23. Summers, S. L., and J. T. Sweeney. 1998. Fraudulently misstated financial statements and insider trading: An empirical analysis. The Accounting Review. 73 (1):131-146.

24. Watts, R. L., and J. L. Zimmerman. 1990. Positive accounting theory: A ten year perspective. The Accounting Review. 65(1): 131-156. 
NOTES 